\title{
Epiphany
}

Epiphany: Vol. 4, No. 1, 2011

ISSN 1840-3719

\section{The European Union in International Politics: Acting as a Global Civilian Power (GCP)}

Bedrudin Brljavac*

\begin{abstract}
During the Cold War the European Community lacking common military instruments was perceived as the example of a civilian power. However, in the early 1990s, under the framework of CFSP, the first concrete defence initiatives have been launched. By the end of the 1990s and after the agreement on the Common Security and Defence Policy (CSDP) the first Rapid Reaction Forces were on the European military agenda. Such defence and military capabilities challenged the idea of the EU as a civil or civilian power. Thus, a main concern in the paper has been to assess the character and identity of the EU`s activities in the context of international relations. For this purpose, this study has explored the EU policy instruments such as the enlargement policy, external aid, environmental policy at the global level, multilateralism, and the EU armed forces. The study concludes that the enlargement policy accounts for an important EU strategy to shape the international environment through civilian means. Furthermore, the international aid policy of the EU states has primarily been based on the sense of duty to other countries as constructivists point out. The EU has also been vocal and has used environmental foreign policy as an instrument to demonstrate its global leadership role which is a clear indication of its commitment to global welfare. Thanks to its presence in the major multilateral interventions of the last decade, the EU has qualified itself as great supporter of multilateralism. Lastly, the EU military capabilities are not achieved by creating permanent European armed forces but are still based on the voluntary contributions of its member states. Therefore, the EU still can be portrayed as a global civilian power (GCP) or civilian power Europe (CPE).
\end{abstract}

Keywords: Civilian power, military power, constructivism, CFSP, CSDP, GCP, and international relations.

* Corresponding author: Bedrudin Brljavac; PhD Candidate, University of Sarajevo, Sarajevo, Bosnia and Herzegovina, e-mail: bedrudin07@yahoo.com 


\section{Nature of the EU's Power}

Without doubt the European Union has become an important actor when it comes to political, economic, and legal questions at the international stage. That is, due to the EU's wide-ranging global involvement and its increased capabilities, it seems to be established that indeed, the EU has a foreign policy (Sjursen, 2006). As Moravcsik argues, "Europeans already wield effective power over peace and war, [...] in the quiet promotion of democracy and development through trade, foreign aid and peacekeeping" (2002). Nevertheless, this also raises the question as to what kind of power it is actually perceived to be in international politics. Hence, from its foundation there have been longrunning academic discussions about the nature of the power of then the $\mathrm{EC}$ and today the EU. To provide an adequate answer to the question it is of crucial importance to analyze the character and features of the EU in regards to its international activities. Starting with the period of the Cold War, the European Community was portrayed as a 'civilian power' in international politics since it did not have relevant military capabilities and relied on economic and diplomatic means in order to influence world affairs (Smith, 1998: 67). In fact, after the rejection of the EDC Treaty by the French national parliament in 1954 defence became a taboo topic among the member states. Indeed, in 1970 the member states leaders established the European Political Cooperation (EPC) as a consultation platform on a voluntary basis excluding any defence subject.

Lacking any defence initiative and strong military instruments Francis Duchene $(1972,1973)$ stressed that the EC is a pure civilian power at the international stage which was 'long on economic power and relatively short on armed force.' Similarly, Manners argues that the EU is primarily a normative power, as opposed to a strictly military power (2006: 184). Although the notions of civilian and normative powers are sometimes used interchangeably this study will evaluate the identity of the EU in terms of its external policies as a civilian power. Indeed, a large number of scholars has believed that the EU influences the world through promotion of its own values, norms and rules based on the notion of civilian power or 'civil power.' That is, as 
Solana argues, a fundamental objective of the EU has become "spreading good governance, supporting social and political reform, dealing with corruption and abuse of power, establishing the rule of law and protecting human rights are the best means of strengthening the international order" (2003). Thus, Andrew Moravcsik claims that the European Union is some kind of a "Quiet superpower" (2002).

All said, it is still highly relevant to discuss the question of the civilian aspect of the EU policies at the international stage. What's more, the EU is a distinctive international actor because it 'exercises influence and shapes its environment through what it is, rather than through what it does` (Maull, 2005: 778). Unlike the previous world powers which promoted their own values, culture and way of life through hard power, the EU has been able to have a considerable influence at international politics through the power of attraction as a civilian power. Thus, in the Constitutional Treaty, the articles I-3 and III-292 state the objectives of the so-called "external action" of the European Union and emphasises the importance of values such as democracy, the rule of law, universality and indivisibility of human rights and fundamental freedoms, the respect of human dignity, the principles of equality and solidarity and, last but not least, the respect for the principles of the UN Charter and international law. In the same spirit, the text favours multilateral solutions to common problems, in particular in the UN framework (Louis, 2007: 15).

Indeed, the EU power is based on its normative appeal as the institutional embodiment of peace and reconciliation, democracy, the rule of law, respect for human rights, liberty, and solidarity which are all enshrined within the acquis communautaire (Aggestam, 2008: 363). For the "normative" school of thought, the European Union should not be a military power in the meaning of a (potentially) aggressive power ("Machtstaat"), and it has to make the best of its exceptional experience of integration, projecting the vision of a Union of values on the global politics (Louis, 2007: 13). Put differently, the EU based on the notion of civilian power has offered an alternative vision of international relations thus provoking the supporters of power politics theory. In addition, the idea of the EU as a civilian power is visible in Jospeh Nye's notion of soft power. That is, Nye asserted that, in addition to economic and military 
power, a third component of power - soft power - "rests on the ability to shape the preferences of others" (Nye, 2004: 5). Also, more than merely influence, he thinks that "soft power is the ability to attract" and he adds that "attraction often leads to acquiescence" (Nye, 2004: 6). However, when it comes to the growing ambition of the European Union member states as a foreign and security policy actor, the limitations of its soft power has become apparent several times. That happened at Dayton and in Kosovo, for instance, so the crisis in the region underlined the limitations of soft power and the need for the EU to have credible military forces to back up its diplomacy if it wished to engage in effective crisis management (Hyde-Price, 2006: 227). In other words, the CFSP was effectively sidelined as the EU's biggest members worked through the Contact Group, in a classic example of 'concert diplomacy' (Holbrooke 1999: 114). Although it may seem at first sight that the EU is "genetically" a civilian power it is still relevant for scholars of international relations to examine the EU's international activities from the angle of civilian power as a possible alternative face of power in world politics. That is, the end of the Cold War might have been expected to usher in an era in which civilian power could be of greater influence: the overwhelming exigencies of defence disappeared, the nuclear standoff was outdated (Smith, 2000: 11). Thus, Joseph Nye asserted that increasing attention could turn to the "real issue - how power is changing in world politics" (1999: 153). As Rifkin points out, probably the Europeans have a very different idea in mind of what ought to constitute a superpower in a today's globalised society (2004: 298). Therefore, in this paper the main concern is to analyze the nature of the EU's power in international relations so the central research question of the paper is: What has been the character or identity of the EU`s activities in the context of international relations?

\section{Theoretical Framework}

In order to systematically provide an analytical explanation to the research question it is of utmost importance to choose a suitable theoretical framework. Before that it is necessary to define the concept of civilian power as an overarching idea which can explain the most 
important policies of the EU states. For instance, Smith defines civilian power as follows, "Civilian is non-military, and includes economic, diplomatic and cultural policy instruments" (Smith, 2004: 1). In order to explore different aspects of the EU as a civilian power in this study we will use the definition of Harnisch and Maull who concluded that the foreign policy identity of a civilian power is characterized by six elements: efforts to constrain the use of force through cooperative and collective security arrangements; efforts to strengthen the rule of law through multilateral cooperation, integration, and partial transfers of sovereignty; promotion of democracy and human rights, both within and between states; promotion of non-violent forms of conflict management and conflict resolution; promotion of social equity and sustainable development; promotion of interdependence and division of labor (Harnisch \& Maull, 2001b: 4).

It is necessary to establish the criteria and assessment standards for examining the character of the $\mathrm{EU}$ 's international role and its putative civilian dimension. For this purpose, this study will cover the EU civilian policies such as enlargement, external aid, environment, peace-keeping, and multilateralism. The study will evaluate these five EU instrument policies in order to analytically justify the thesis of EU as a global civilian power (GCP). Through the analysis of the above themes the answer ought to be provided to the research question of the study.

Since the study examines the concept of civilian power in the context of EU foreign policy we will use a constructivist perspective in order to support the central line of thought. In contrast to rationalist argument of EU foreign policy, constructivist theory seems more relevant here since the idea of a civilian power Europe or GCP is predominantly based on immaterial features such as identity, values, norms, culture, way of life, and ideas (Waever, 2000: 333). That is, constructivist theory is based on the understanding of the world around us as a socially constructed giving greater weight to the social dimension than to the material in the context of international politics (Checkel, 2008: 73). Therefore, the EU foreign policy highly depends on a shared understanding among member states` leaders and ordinary citizens about the global role of the EU and about the values and ideas it should 
promote and defend (Keukeleire, S. \& MacNaughton, J., 2008: 334). Although it is not easy to agree on shared ideas and values it is said that EU`s core norms are liberty, democracy, respect for human rights and fundamental freedoms, and rule of law; and minor norms, such as social solidarity, non-discrimination, sustainable development and good governance (Orbie, 2008: 18).

In contrast, realist thinkers argue that states do not feel much of a duty to others and their national interest is defined by the quest for survival and power (Barnett, 2008: 192). Lebow also cites Mearsheimer's characterisation of this anarchical international system as "a brutal arena where states look for opportunities to take advantage of each other" (2007: 55). Thus, according to realist school of thought international relations "cannot escape from a state of anarchy and will continue to be dangerous as a result" (Goldstein \& Pevehouse, 2006: 74). Thus, realists thinkers have a largely pessimistic worldview about the state of international relations. Although state interests are important in international relations they have played secondary role in the context of the EU`s foreign policy. As Weitsman argues, the EU looks like it was not simply an alliance formed against an adversary, but one that was formed between adversaries, thus improving "the chances of enduring peace among Union members" (1997: 191).

\section{Enlargement Policy of the European Union}

The 1995 enlargement to three former European Free Trade Association (EFTA) members, the acknowledgment of the candidate status of thirteen further countries and the extension of the membership perspective to the western Balkans, have made enlargement a permanent and continuous item on the EU's agenda (Schimmelfennig \& Sedelmeier, 2002: 500). Thus, the enlargement policy of the EU is widely seen as the most important aspect of EU foreign policy which substantially challenges realist arguments claiming that state interests are the basis of international relations. Beside being important as a political project the enlargement of the European Union (EU) has been a difficult challenge facing Europe in the post-cold war period (Sjursen, 2002: 491). The enlargement process has been described as a process of 'horizontal 
institutionalisation' whereby the EU's organisational norms and rules are extended territorially (Schimmelfennig \& Sedelmeier, 2005). Still, the enlargement process might alternatively be typed as 'vertical institutionalisation' given the top-down approach taken by the European Union (Pridham, 2010: 448). Although costs to the EU member states have been high the enlargement policy is accepted as the most successful instrument to promote the values and ideals that EU member states support. For instance, in the Amsterdam Treaty 1999 it is stated that `any European state that respects the principles of liberty, democracy, respect for human rights and fundamental freedoms, and the rule of law, may apply to become a member of the Union (Articles 5 and 49).

Purely materialist or realist arguments can not satisfactorily explain why the member states should shoulder considerable costs by accepting usually very poor and underdeveloped countries which can also have negative repercussions on the effective functioning of the EU itself (Smith, S., Hadfield, A., \& Dunne, T., 2008: 374). Therefore, identity, values and norms have played very considerable role in the process of enlargement and substantially strengthening constructivist perspective. The EU has extensively used both carrots and sticks in its relations with applicant countries thus reflecting its character of civilian power exercised through soft power of attraction (Smith, 2005: 271). The enlargement policy accounts for an important EU strategy to shape the international environment through civilian means. Indeed, the EU`s enlargement policy is the best indication of civilian power Europe (CPE) or GCP since its central premises are enshrined in the magnetism and power of attraction that the EU possess. Also, enlargement policy of the EU can not be perceived as a hegemonic project since it is up to the national governments to make decisions whether to enter the EU or not. As Schimmelfennig and Sedelmeier argue, new members of the organization may even negotiate post-accession transition periods before applying some of its norms and rules, or they might begin to participate in some of the organization's policies at different times, as is the case in the EMU or the Schengen Agreement (2002: 503). Also, it is not clearcut from the beginning that an enlargement process will result in positive changes or economic gains for the current members of the EU. For 
instance, not only does enlargement threaten to disturb the internal order of the EU, the new external borders that will follow from the expansion could also create new divisions on the European continent and thus foster instability in Europe at large (Sjursen, 2002: 491).

The largest success of the EU foreign policy so far relates to reshaping the identity, values and norms of the Central and Eastern European Countries (CEEC) (Keukeleire, S. \& MacNaughton, J., 2008: 334). Accession of the countries of CEE to the EU has meant a historical moment since these countries transformed and reshaped their political, economic, social, and ideational systems in order to become part of free and democratic world. That is, Maull claims that "In Central and Eastern Europe, the prospect of enlargement has probably made a huge contribution to regional stability, prosperity and the progress of liberal democracy" (2005: 782). Indeed, the EU has put special emphasis and substantially has helped strengthen democracy promotion in the CEE. Thus, Dimitrova and Pridham point out that, "a new model of democracy promotion has been emerging with respect to central and eastern Europe, namely democracy promotion through integration. Just as the European Union has been considered a system of governance sui generis, unique among international organizations, so democracy promotion through integration has evolved in the last decade as a somewhat unique way of promoting democracy" (2004: 94). Pridham goes further pointing out that without question the most pivotal European instrument for democracy promotion has been the European Union, including first and foremost the accession process but also the direct assistance programs provided by the European Union to new democracies (2005). In fact, democracy promotion has been achieved through the adoption of EU rules in nonmember states, i.e. their institutionalization at the domestic level. Such institutionalization includes the transposition of EU legislation into domestic law, the restructuring of domestic institutions according to EU rules, or the change of domestic political practices according to EU standards (Schimmelfennig \& Sedelmeier, 2004: 670).

Symbolically, the new democracies of Central and Eastern Europe have viewed EU membership as their `return to Europe` after the bipolar world of the Cold War (Sedelmeier, 2005a: 407). The transformation of 
their stagnant political, economic, and social systems in the aftermath of the collapse of communism was explicitly organized in the framework of their strong commitment to core European values and norms (Smith, S., Hadfield, A., \& Dunne, T., 2008: 367). Furthermore, the enlargement issue is a question of morality and shared identity as Blair pointed out once, "but I do believe that we have a moral duty to offer them the hope of membership of the EU..." (Blair, 1999: 371). In a similar tone, Coffey speaks of a moral obligation on the part of the western states to help the former communist countries of central and eastern Europe, on the basis that it earlier encouraged them to overthrow communist regime (1995: 96). Although the argument about political conditionality as a coercive instrument seems reasonable to some extent, it is clear that member states are prepared to accept every risk that enlargement would bring to them (Smith, S., Hadfield, A., \& Dunne, T., 2008: 374). That is, current member states are aware of the fact that before and after each enlargement cycle they have to pay some costs. So, it is too straightforward to view the enlargement simply reflecting the concern of the EU to maximize the benefits to current members as Preston puts it (1997: 9).

\section{The External Aid Policy of the European Union}

Aid policy in the EU for the developing countries is a shared competence between the Union, administered primarily by the European Commission, and the member states. Although the topic is sometimes undermined, the external aid provided by the EU member states accounts for an important instrument of civilian power in terms of foreign policy activities. As Sefano argues "Development is at the heart of the external action of the EU. (...) Together with other component of EU's external action development policy is about projecting political stability, economic prosperity and solidarity. It is thus a policy of values, but is also a policy of influence and interest" (2006: 5). Thus, Arts and Dickson views the EU aid and development policy as having shifted from a classical model of north-south relations to an assertion of the EU's identity in the international stage (2004). The objective of EU aid is the eradication of poverty in the context of sustainable development, in line 
with the Millennium Development Goals (MDGs) (DSW, 2010: 1). Thus, the EU and its member states together are the largest aid donor in the world. It seems that Romano Prodi's message has become closer and closer to truth when he pointed out that, "We must aim to become a global civil power at the service of sustainable global development. After all, only by ensuring sustainable global development can Europe guarantee its own strategic security" (Prodi, 2000). The aid programmes of the EU member states accounted exactly $62,10 \%$ of all ODA aid donations (see Figure 1).

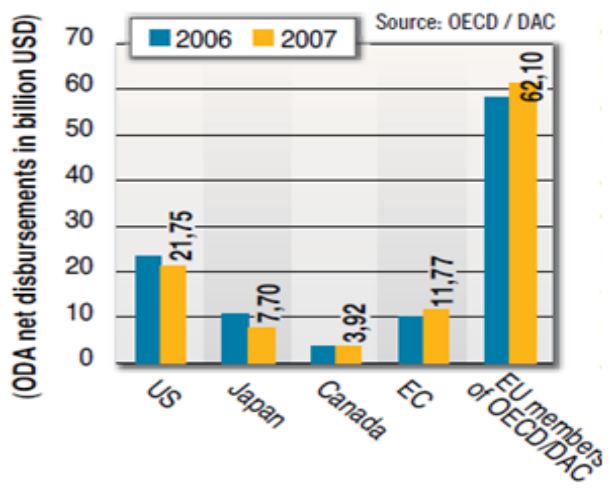

Figure 1. Extemal Aid

However, the EU has been criticized for being ineffective and nontransparent in its placement of aid programs. In response to criticism about the effectiveness of its aid activities, the European Union has embarked on a series of reforms. For instance, Oxfam concluded that "EC aid for the large part is significantly more effective than it was a decade ago" (2010: 9).

Furthermore, the EU and its member states paid out more than $€ 49$ billion in 2008 in external aid to developing countries what accounted for the equivalent of $0.40 \%$ of their GNP, and was higher than the per capita aid levels of the United States or Japan (European Commission, 2008). Although some analysts argue that the EU aid is unequally delivered depending on the geo-strategic interests of the members states it is clear that the truth is quite different since EU aid is more evenly spread around the world than that of other aid donors such as the US and Japan. For instance, 55 countries receive more than $50 \%$ 
of their total development aid from the EU, while the US aid is primarily concentrated on the Middle East and that of Japan on Asian countries (Keukeleire, S. \& MacNaughton, J., 2008: 215). Such an equal distribution of the EU aid is the best indicator that member states international aid is primarily based on an ideal of solidarity and sense of duty to other countries as constructivists point out. The EU aid is guided by the following policy documents:

- The 2005 European Consensus on Development,

- The 2005 revised Cotonou Agreement,

- The 2006 Regulation establishing a Financing Instrument for Development Cooperation,

- Increased budget support (target: 50\% of EU aid),

- Decreased disbursement of aid through programmes and projects,

- Commitment to involve Civil Society (DSW, 2010: 1).

In order to better understand the extent to which the EU member states use their external development or humanitarian aid as an instrument of civilian power it is of utmost significance to mention concrete examples where the aid arrived. For instance, the African continent was among the first recipients of the development aid, beginning in 1963 in the form of the Younde Convention between then EC and 18 African countries. Today, under the framework of Cotonou Agreement since the June 200071 ACP states (48 countries form SubSahara Africa, 16 from the Caribbean and 15 from the Pacific) are covered making it the largest coherent aid programme for non-members of the EU (Hill \& Smith, 2005: 165). In the context of the beginning Cotonou negotiations in June 1998, Charles Josselin, the French Minister for Cooperation, stressed that "the maintenance of a specific convention between the European Union and the ACP states is an essential element of the inalienable solidarity between Europe and Africa" (1999: 9). Thus, since 2000, the vast majority of European Commission general budget support has been allocated to African, Caribbean and Pacific countries (OECD/DAC, 2008). Although the EU started to shift its priorities from the ACP countries to the Central and Eastern European region in the 
1990s the ACP region still remains the major recipients of EU aid (European Commission, 2000: 36).

Furthermore, the EU has been the largest aid donor in Afghanistan concerning reconstruction and humanitarian projects spending about 800 million Euros in the year after the war started and providing further 1, 9 billion Euros for 2002-2006 at the January 2002 donor conference in Tokyo (Hill \& Smith, 2005: 168). In addition, the EU member states have been collectively the single largest donor in Palestine endorsing a plan to focus aid on "sustainable, long-term economic development," amounting to approximately $\$ 1.47$ billion over the next three years (AP, 2008). Also, in August 2008 the EC had committed 401.5 million euros - 216 for recurrent expenditures, 53 for development projects, 71 for UNRWA, 8 for Nahr el Bared (emergency aid), 29.5 for food aid and 24 for humanitarian aid (European Commission, 2008). Thus, regarding the EU aid to Palestine Herremans claims that "For the EU it was crucial to increase living standards in the [occupied territories]. Tangible benefits such as higher income and improved infrastructure would entail popular satisfaction with the peace process" (2007). Also, the EU, both its member states and the European Commission, is visible as the single largest donor in South East Europe, providing humanitarian aid and assistance for economic reconstruction in the region (Calic, 2005: 11). Thus, it is important that EU external aid recipients are concentrated at a number of regions as stated in the Figure 2.

\begin{tabular}{|l|l|}
\hline Regional distribution of Community aid & \$ millions \\
\hline Sub-Saharan Africa & 2028 \\
\hline Europe & 1413 \\
\hline Middle East/North Africa & 635 \\
\hline Latin America/Caribbean & 552 \\
\hline South/Central Asia & 419 \\
\hline Other Asia/Oceania & 323 \\
\hline
\end{tabular}

Figure 2. Regional distribution of aid

Source: OECD `Aid at a Glance` charts for DAC countries, 2002. 


\section{The European Union and Global Environmental Protection}

The EU has played a very constructive and substantial role in the international stage in the context of environmental policies since it has been setting climate standards in order to protect whole world from dangerous emissions which is firmly in line with constructivist argument of the idea of 'internationalization`. Better to say, the growing power of environmental interests in the European Union states from the late 1980s coupled with strong initiatives of EU policy-making led the Union to develop ambitious and comprehensive environmental policies. Thus, after the first United Nations Conference on the Environment in Stockholm in 1972, the European Commission became active in initiating first Community policies in this field. Furthermore, on the basis of European Council commitments in 1972 to establish a Community environmental policy, the first Environmental Action Program (EAP) was decided upon in November 1973. Thus, more than 70 environmental directives were adopted between 1973 and 1983 (Vogel et.al., 2010: 2). However, it was not until the Single European Act (SEA) in 1986 that the environmental issues secured a treaty base, which was confirmed and later consolidated in the TEU and later treaties of the EU. In addition, article 174 of the TEC on Environmental policy explicitly states that 'promoting measures at international level to deal with regional or worldwide environmental problems` is the critical objective where the EU has been doing a lot. In other words, external environmental policy has been a very important part of the EU`s foreign policy arsenal since through this policy the EU seeks to pursue milieu goals and global public goods (Keukeleire, S. \& MacNaughton, J., 2008: 246). Thus, the European Union has been described as "having the most progressive environmental policies of any state in the world although it is not a state" (Jordan, 1999: 1).

Furthermore, after the US gradually left the leadership position in global environmental policy the EU established itself as the new leader setting new global environmental goals (Vogler, 2005: 835). Certainly, the US shift from global environmental leader in the 1970s and 1980s to laggard and obstructionist in the 1990s and 2000s opened an opportunity for the EU to assert its leadership (Sbragia and Damro, 1999). The EU has played the most visible role within the negotiations of the Kyoto 
protocol while the US completely rejected to ratify such an agreement. Such an opposing tendency reflects their different understandings of environmental issues since the US is closer to market-led strategies and to a 'use-with-risk strategy' while the EU`s tendency is `a more cautious, risk aversion strategy (Baker, 2006: 92). Also, different understandings of agri-environmental policy and of its aims has also been identified, for example the absence in the US of the EU goal of using these not only to control pollution or erosion but also as drivers of rural development (Baylis, et al., 2008). Furthermore, the European Union has become a model for significant economic shifts based on "innovative environmental policy" required of all countries with a carbon-based economy. Thus, the EU is much further along the inevitable path towards a low-carbon economy than any other part of the world (Brunnée and Levin, 2008: 71). Furthermore, starting in 1999, the EU has required all new cars sold within the EU to display labels indicating their fuel efficiency and carbon dioxide emissions. Most recently, a regulation enacted in 2009 requires auto manufactures to limit their fleet-wide average carbon dioxide emissions or pay an 'emissions premium' (penalty) (European Parliament, 2009). What is more, the EU has been enforcing environment-based standards and rules through its legislative bodies. Thus, the European Court of Justice has been monitoring implementation through transposition and regulatory action of EU environmental rules, as in the highlighting of Ireland and other countries for failings in connection with the Wild Birds and Habitats Directives (Vandenberghe, 2008). Also, the EU also issued a directive specifically addressing energy efficiency in 2006 which calls for five-year action plans to be developed by the European Commission towards achieving the EU's goal of 20 per cent reduction in consumption of primary energy by 2020, and has established energy savings target of 9 per cent to be reached within nine years (i.e., 1 per cent annually), starting in 2008 (European Parliament, 2006). Last but not least, extensive constitutional and political checks have been agreed upon in the EU on the influence of large states which can block them from substantially manipulating the process of the environmental protection in their favor (Archer and Nugent, 2006). 
In addition, the EU`s constructive activism and the US`s rather passive or ignorant approach regarding global environmental issues clearly demonstrate sincere duty that member states feel against both their home populations and other overseas lands. For instance, in 2001 when the US government announced that they will not ratify the Kyoto Protocol which threatened its coming into life it was the EU that saved the whole process after making Russia accepting to ratify the Protocol. That is, the EU supported Russian membership into the WTO on its agreement to ratify the Kyoto Protocol which was achieved in 2004 (Bretherton \& Vogler, 2006: 109). Obviously, the EU has successfully and very visibly used environmental foreign policy as an instrument to display its global leadership role which is a clear indication of its commitment to ideals such as solidarity and global welfare. That is, the EU has demonstrated clearly that its support for international environmental treaties is not determined by domestic interests, but rather is 'constructed' by a 'world environmental regime' (Meyer, et al., 1997). Such a strong commitment to sustainable development and global welfare is clearly in line with Harnisch \& Maull`s definition of civilian power. In fact, we can conclude that Kyoto has become more important as an identity goal than as a policy goal which is clear from the difficulties EU member states faced ratifying the process and complying with Kyoto targets (Keukeleire, S. \& MacNaughton, J., 2008: 248). Also, just ahead of the Copenhagen Climate Summit the EU leaders agreed to an increase of the bloc`s commitment to greenhouse gas reductions from previous target of 20 percent to 30 percent while the US government has not showed much interest towards more concrete agreement so far. As Vogel et. al., argues "important initiatives and commitments to reduce emissions of greenhouse gases have been undertaken in the EU at both the central and state levels with one often complementing and reinforcing the other. In the US, by contrast, federal regulations restricting greenhouse gases had yet to be implemented as of early 2010" (2010: 5). Thus, while all EU member states have adopted climate change policies, many states in the US have not done it. Probably it has been close to the truth that Europeans are from Mars while Americans are from Venus, to use Kagan`s famous term (Kagan, 2003). 


\section{The European Union and Principle of Multilateralism}

In today's global politics a large number of international organizations, and especially the United Nations, have a strategic tendency to maintain the idea of multilateralism, the practice of contemporary world politics based on shared principles and mechanisms that increasingly influence international relations and also domestic affairs. The EU, thanks to its presence and actions in the major multilateral interventions of the last decade, qualifies itself as great supporter of this policy (Attina, 2008: 2). The EU leaders have been firmly in support of cooperative actions with other world actors at the international stage since they explicitly have demonstrated their commitment to an ideal of multilateralism and global cooperation. For this reason, the EU is generally perceived as a great supporter of a global order which is primarily based on international organizations and rulesitself an external reflection of the EU`s internal attempts to establish interstate relations on common principles and institutions (Keukeleire, S. \& MacNaughton, J., 2008: 299). For instance, the TEU puts that foreign and security policy objectives of the EU are to be pursued in accordance with the principles and rules of the UN Charter and of the OSCE (Art. 11 TEU). Therefore, the very basis or the fundamental doctrine of the international presence of the EU has been built upon the most relevant and widely accepted international rules, principles and regulations. Simply said, the EU's ideology in regards to international politics has been the policy of multilateralism.

Even more indicative has been the European Commission's communication with a very comprehensible title 'The European Union and the United Nations: the choice for multilateralism' (Louis 2007: 15). To put it differently, the EU member states have made principle of multilateralism a constant policy and strategic behaviour of their international relations context (Mayer \& Vogt, 2006: 49). Since the EU is an international rules-oriented community it is outlining the picture of the peaceful, cooperative and soft world power. As Marsh and Mackenstein conclude: "It [i.e. the EU] clearly has a significant global presence and a 'Mister Nice Guy' image in international relations on account of its devout multilateralism and its traditionally non-coercive approach to its 
external relations. This image is encouraged both by EU actions frequently reflecting its principles and by comparison with other leading powers, notably the US." (2005: 251). While the US has traditionally been building its image of the superpower upon the unilateral policymaking excluding other global actors, the EU has on the other hand demonstrated the vision of the most cooperative and multilateral-oriented organization in the world. That is, while the US international policies are aimed at the realization of the doctrine of hegemonic power the EU itself is pushing the principle of equality of the world states. At a global level, the EU acts as a community which traditionally tends to develop a stronger and more secure international society. Therefore, it is of utmost importance to pursue regular negotiations and dialogue with other global players in order to reach a constructive compromise and mutual agreement.

In a similar vein, collective experience in regional integration of the member states has made Europeans naturally more inclined than the other global influential power at the international level, the United States, to contemplate multilateral rules, regulations, and institutions for the management of global interdependence (Hill \& Smith, 2005: 238). Even the ESS, as a comprehensive security strategy is based on dialogue, bargaining, cooperation, partnership and institutionalized, rules-based multilateralism (Howorth, 2007: 204). The two strategic objectives can be identified within the ESS, namely, building security in Europe's neighborhood and promotion of an international environment that is based on effective multilateralism (ESS, 2003). In fact, the ESS has been built on the strategic premise that "'leave no room for an alternative' to multilateral action" (Mitzen 2006: 283). Such a tendency is the best indicator of the EU as a GCP exerting influence virtually through multilateral channels. That is to say, in terms of protection of environment the EU has been globally perceived as a civilian power in pursuit of a rule-based global governance. The EU leaders are more than aware that only by following internationally accepted rules and conventions it is possible to create a peaceful and prosperous world.

When we come to the real world there have been many examples where the EU member states sought to work together with other global 
actors to solve international problems. Indeed, the EU has constantly defended the institutional strengthening of international organizations such as the UN, NATO and the WTO, and also actively promoting the construction of new global regimes as well as the strengthening of the global civilian policies (Telo, 2007: 54). Therefore, since the early 2000s, the EU displayed very proactive attitude towards the multilateral policymaking together with UN. In this respect, in 2001 the European Commission agreed in the Communication on "Building an effective partnership with the United Nations in the fields of development and humanitarian affairs". Furthermore, if EU foreign policy has been successful in the Balkans region the main reason is that its actions were carried out in cooperation with the UN, the World Bank, the OSCE, the Council of Europe and NATO (Keukeleire, S. \& MacNaughton, J., 2008: 302). In the financial sector, for instance, EU states contribute about $38 \%$ of the ordinary budget, $50 \%$ of the contributions to special funds and programs, and 40\% of the UN peace operations costs (Attina, 2008: 7). Therefore, the EU does not nourish the tendency to set the hegemony at the international arena but its fundamental global policy revolves around the cooperation and joint adventures with other prominent international organizations in the world.

Such a cosmopolitan approach to global governance is a very clear message that the EU leaders are more than ready to work in cooperation and sharing information, knowledge, and even military and other infrastructure tools with other global actors in order to promote democratic values, human rights and the rule of law. Simply, the EU's international activities are directed towards the "production of public goods" that is aimed at the wellbeing and prosperity of the whole of mankind. In other words, the EU has had a tendency to overcome power politics through multilateral cooperation in international affairs as Harnisch and Maull concluded in their conceptualization of civilian power. Put differently, any organization, institution, or a country must explicitly demonstrate its will and commitment to global cooperation if it is to maintain itself as a relevant actor in today's era of global interdependence. The EU is just doing the perfect job in this respect as a GCP. Similarly, Maull argues that a Civilian Power concentrates mainly 
on non-military, economic means to achieve its objectives, emphasizes multilateral cooperation, and develops supranational structures to cope with international problems, and thus perceives "the military as a residual safeguard" (McCormick: 2007: 70). All that being said, in today`s conditions of global governance it is the EU which is the best equipped actor to promote and defend the idea of multilateralism (Mayer \& Vogt, 2006: 71). Putting the emphasis on multilateral intervention at international affairs the EU is proving itself as an uncompromising and strong civilian power.

\section{The EU's Common Defence Policy?}

From the early 1990s the idea of 'the civilian power Europe' has been challenged by serious military and defence initiatives made by the EU leaders. Firstly, in November 1993 within the framework of the Maastricht Treaty the Common Foreign and Security Policy (CFSP) of the EU came into force. The CFSP constituted one of three institutional "pillars" of the EU and a platform for the development of the common European defence (Duke, 2000). The new security policy even included the formulation of the eventual framing of a common defence policy which might in turn lead to a common defence'. Furthermore, by the end of the 1990s after the agreement on the Common Security and Defence Policy (CSDP) the idea of the civil or civilian power of the EU has come under serious threat. Also, such ambitious agenda was further strengthened during the European Council in 1999, which pointed out that the EU "must have the capacity for autonomous action, backed up by credible military forces, the means to decide to use them, and a readiness to do so, in order to respond to international crises without prejudice to actions by NATO" (Cologne European Council, 1999). As Howorth pointed out, 'genie was out of the bottle and the common defence project had begun to take on a life of its own` (2000:31).

Furthermore, at the Helsinki Summit of 1999 the EU leaders produced the 'Headline Goals` agreeing that 'cooperating voluntarily in EU-led operations, member states must be able by 2003, to deploy within sixty days and to sustain for at least one year military forces up to 50 000-60 000 persons capable of the full range of Petersburg Tasks` (HEC: 
2000). Such new responsibilities agreed by the EU states included "humanitarian and rescue tasks, peacekeeping tasks and tasks of combat forces in crisis management, including peacemaking" (Foster, 2005: 96). Thus, it was the first time in EU history that the idea of "combat forces," meaning an open possibility of military activities, was mentioned. Indeed, without doubt since the end of the Cold War there have been serious initiatives and calls for common defence of the EU states. For instance, the Belgian Prime Minister Verhofstadt recently supported the idea of a common defence in his pamphlet on "The United States of Europe" (2005). In addition, the Lisbon Treaty contains a set of changes designed to make the EU a more coherent actor in the field of CFSP. For instance, one of the most important institutional changes has been the creation of the post of a High Representative of the EU for Foreign Affairs and Security Policy. Thus, the EU clearly displays that the continuing development of the common and stronger security and foreign policy of the EU states is essential to the Union's aspirations to be a global actor. However, the EU's use of military and defense instruments will probably undermine its 'soft power' and its positive image as a civilian actor in the international politics (Smith, 2004: 261). All said, it is clear that the notion of the CPE has faced serious challenges for several times with every new military or defence initiative at the EU level.

However, such attempts do not demonstrate that the idea of the civilian power Europe (CPE) is distorted as some scholars point out (Acikmese, 2002: 11). For instance, now a decade from Saint Malo Agreement the EU member states have not yet successfully created a European army in a conventional sense as in the normal states. What is more, the acquired military capabilities and instruments are just "one of the Union's tools, where civilian means continue to occupy a central position" (Smith, 2004: 9). Also, EU military capabilities are not achieved by creating permanent European armed forces, and even less by establishing a permanent EU army, but are based on the voluntary and temporary contributions of member states (Keukeleire, S. \& MacNaughton, J., 2008: 179). In other words, as the expectations of EU foreign policy and military capabilities were not matched it seems that there existed serious `capabilities-expectation gap` as Hill claimed (Hill, 
1993). What is more, different interests of the EU states regarding their foreign policy have prevented Brussels to become a more visible actor at the international level. In other words, the lack of strategic vision among the EU states is reflected in the debates in the literature about the nature of the Union's international role, especially when it comes to security matters (Sjursen, 2006). As Keukeleire claims that "too many states but also too many issues and subjects which are not of common interest for all the states present around the Council's table, are problems accentuated by the 2004 and 2007 enlargements" (2006). Further, the EU is highly dependent on the NATO military capabilities and technical infrastructure. Paradoxically, ESDP highly needs NATO to provide access both to military instruments and to planning facilities and to help the EU acquire an autonomous military capacity (Howorth, 2007: 176).

As Maull has summed up the situation of Europe vis-à-vis the US in the following words: "From the beginning of the Cold War and beyond its demise, the US has been serving as the (free) world's government by default. The EU has been acting broadly as its junior partner - no less, but also not much more" (2006: 85). As a group of economists claims in a report prepared for the Finnish Presidency on "The EU and the governance of globalisation": "Europeans have rarely set the agenda. They have often responded to new developments in a reactive manner" (Ahearne, et al, 2006: 31). In addition, the ESDP operations can be military, civilian or a combination of the both. For instance, although the EU carries out military operations the multitude of civilian operations has been far higher as stated in Figure 3. Although the quantitative dimension of the foreign policy may not be such a reliable data, it can help us to understand the significance and priority the EU has given to civilian missions in comparison to military ones. What is more, military actions carried out by the EU tend to protect and promote universal rights and freedoms. Therefore, Rifkin points out that "the goal is to minimise casualties on all sides of the conflict, [...] Soldiers are risking their lives in order to save the lives of civilians [for humanity]" (2004: 304). In addition, so far the EU has, for example, been active in very dangerous and troubling countries and regions such as the Sudan (Darfur region), Afghanistan or in Indonesia (Aceh region) (European Union, 2006). 


\begin{tabular}{|l|l|}
\hline Type of Operation & Number of Operations* \\
\hline Military & 4 \\
\hline Civilian & 13 \\
\hline Military/Civilian & 1 \\
\hline
\end{tabular}

Figure 3. Overview of ESDP Operations

*The overview is based on number of operations carried out up to June 2007.

\section{Conclusions and Reflections on the Future}

Given the fact that defence and military topics were a taboo subject in the European Community in the aftermath of rejection of EDC by the French Assembly and facing serious lack of common military capabilities for a long time, the Community was perceived by many scholars as a purely civilian or civil power giving priority to civilian and non-military instruments to military ones regarding the context of international relations. However, increasing military and defence initiatives and capacity starting in the early 1990s and strengthening after CSDP came into life the notion of 'civilian power Europe' has faced serious challenges. Further, the new security strategy document included the formulation of the eventual framing of a common defence policy which might in turn lead to a common defence`. However, now a decade from the Saint Malo Agreement, which for many meant a new era in 'EU military capacity development,' the member states have not yet successfully created a European army in a conventional sense as in the normal states. In addition, EU defence and military capacity is based on the voluntary and temporary contributions of member states and highly dependent on NATO military instruments in the framework of the Berlin Plus. For instance, ESS asserts the importance of the transatlantic alliance and it especially emphasizes the EU-NATO permanent arrangements, in particular Berlin Plus, which "enhance the operational capability of the EU and provide the framework for the strategic partnership between the two organisations in crisis management" (EC, 2003: 12). Therefore, it is still relevant and reasonable to conceptualize the character and nature of the EU in global affairs as primarily a civilian power rather than a 
military power as many prominent scholars point out. In order to justify this argument in the study, the five case examples have been presented, namely the enlargement policy with emphasis on CEE enlargement, external aid, environmental policy at global level, multilateral approach to global governance, and serious shortcomings in development of the EU armed forces in a conventional sense.

If historical experiences can teach us important and insightful lessons for the future then it is a high probability that the European Union member states in the next decade or two will continue to act in global affairs primarily as a civilian power rather than military. Although the EU has initiated some defence, security, and military capacity over the last two decades, it is clear that the EU has had at its possession an entire spectrum of policy instruments, amongst which are the five cases we evaluated here, necessary to effectively promote the `civilizing` of global affairs. As constructivists point out the EU has demonstrated continuous willingness to defend universal principles and express a strong duty to other countries or world events such as the Kyoto Protocol or external aid, for instance. In other words, it is very difficult for realist thinkers to justify their explanation based on pure national interests with regard to the case examples presented above. As Smith points out, "the EU still clearly prefers civilian to coercive military measures" (Smith, 2003: 111). That's way the EU is said to account for and continue to provide in the future a new internationalist model in global affairs basically rejecting the notion of power politics. However, there have been clear "limits of a civilian power in a rather uncivilized world" as seen from complete impotence of the EU during the Yugoslavian conflicts in the early 1990s (Pijpers,1988: 162). Therefore, it is worth carrying out an in-depth academic research on whether military capabilities should be used by the EU in order to promote its civilian objectives.

\section{References}

Acikmese, S. A., (2002). Has the period of the civilian power Europe come to an end? Ankara Review of European Studies, 2 (3), 1-14.

Aggestam, L. (2008). New actors, new foreign policy: EU and enlargement. In Smith, S., Hadfield, A., \& Dunne, T. (Eds.). 
Foreign policy, theories, actors, cases. (pp. 359-377) Oxford: Oxford University Press.

Ahearne, A., Pisani-Ferry, J., Sapir, A., \& Véron, N. (2006). The EU and the governance of globalisation. Bruegel Working Paper, No. 2006/02.

AP, Associated Press. (2008). EU adjusts Palestinian aid program to target government's goals. The Jerusalem Post, 28 January 2008.

Archer, C., \& Neill, N. (2006). Does the size of member states matter in the EU?. Journal of European Integration, 28(1), 3-6.

Arts, K. \& Dickson, A. (2004). EU development cooperation: From model to symbol. Manchester: University Press.

Attina, F. (2008). Managing globalisation: EU's effective multilateralism. Jean Monnet Working Papers in Comparative and International Politics, September 2008, JMWP no. 65.

Baker, S. (2006). Environmental values and climate change policy. In S. Lucarelli \& I. Manners (eds.). Values and principles in EU foreign policy. (pp. 77-98). London: Routledge.

Barnett, M. (2008). Duties beyond borders. In Smith, S., Hadfield, A., \& Dunne, T. (Eds.). Foreign policy, theories, actors, cases. (pp. 189-205). Oxford: University Press.

Baylis, K., Peplour, S., Rausser, G., \& Simon, L. (2008). Agrienvironmental Policies in the EU and US: A Comparison. Ecological Economics, 65 (4), 753-64.

Blair, T. (1999). New challenge for Europe. In Smith, S., Hadfield, A., \& Dunne, T. (Eds.). Foreign policy, theories, actors, cases. Oxford: University Press.

Bretherton, C. \& Vogler, J. (2006). The European Union as a global actor. London: Routledge.

Brunnée, J., \& Kelly, L. (2008). Climate policy beyond Kyoto: The Perspective of the European Union. In Steven Bernstein, Jutta Brunnée, David G. Duff, and Andrew J. Green (eds), A globally integrated climate policy for Canada. Toronto: University of Toronto Press. 
Calic, M.J. (2005). The Western Balkans on the road towards European Integration. Internationale Politikanalyse Frieden und Sicherheit, Dezember 2005.

Checkel, T.J. (2008). Constructivism and foreign policy. In Smith, S., Hadfield, A., and Dunne, T. (Eds.). Foreign policy, theories, actors, cases. Oxford: University Press.

Coffey, P. (1995). The future of Europe. London: Edward Elgar.

Council of the European Union. (1999). Cologne European Council Conclusions.

Dimitrova, A., \& Pridham, G. (2004). International actors and democracy promotion in Central and Eastern Europe: The integration model and its limits. Democratization, 11 (5), 91-112.

DSW. (2010). EU aid for sexual and reproductive health in Rwanda. German Foundation for World Population (DSW), Fast Facts, June 2010.

Duchene, F. (1972). Europe`s role in world peace. In Richard Mayne (Eds.). Europe tomorrow: sixteen Europeans look ahead. London: Fontana.

Duchene, F. (1973). The European Community and the uncertainties of independence. In Kohnstamm, M., \& Hager, W. (Eds.). A nation writ large? Foreign policy problems before the EC. (pp. 1-21). Basingstoke: Macmillan.

Duke, S. (2000). The elusive quest for European security: From EDC to CFSP. Basingstoke, Macmillan, 2000.

EC. (2003). European security strategy. European Council, December 2003.

European Commission. (2000). Communication from the commission to the Council and the European Parliament. The European Community's Development Policy. COM (2000) 212 final. Bruxelles 2000.

European Commission. (2008). Europe web portal.

European Commission. (2008). EC assistance to the Palestinians in 2008. August 2008.

European Parliament. (2006). Directive 2006/32/EC of the European Parliament and of the Council of 5 April 2006 on energy end-use 
efficiency and energy services and repealing Council Directive 93/76/EEC. Official Journal L114, April 27, 2006, p. 0064-0084.

European Parliament. (2009). Directive 2009/29/EC of 23 April 2009 amending Directive 2003/87/EC so as to improve and extend the greenhouse gas emission allowance trading scheme of the Community. Official Journal L140, June 6, 2009, p. 0063-0087.

European Union. (2006). Partnership Agreements.

Foster, N. (2005). Blackstone's EC Legislation 2004-2005. Oxford: University Press.

Goldstein, J.S., \& Pevehouse, J.C. (2006). International relations. 7th Ed. Pearson Longman, London.

Harnisch, S., \& Maull, H. (2001b). Introduction. In S. Harnisch \& H. Maull (Eds.). Germany as a civilian power? The foreign policy of the Berlin Republic. Manchester: Manchester University Press.

Helsinki European Council (HEC). (2000). Bulletin of the European Communities, No 12/1999, Luxemburg, Office for Official Publications of the European Communities, 2000, paragraph 28.

Herremans, B. (2007). EU aid to the occupied Palestinian territories: abetting occupation? Draft, 2007. EC Technical Office, Overview of EU Relations with the Palestinians.

Hill, C. (1993). Capability-expectations gap, or conceptualizing Europe`s international role. Journal of Common Market Studies, 31 (3), 305-28.

Hill, C., \& Smith, M. (2005). International relations and the European Union. Oxford: University Press.

Holbrooke, R. (1999). To End a War. New York: The Modern Library.

Howorth, J. (2000). European integration and defence: The ultimate challenge?. WEU Institute of Security Studies, Chaillot Paper No. 43, November 2000.

Howorth, J. (2007). Security and defence policy in the European Union. Basingstoke: Palgrave Macmillan.

Hyde-Price, A. (2006). 'Normative' power Europe: a realist critique. Journal of European Public Policy, 13 (2), 217-234. 
Jordan, A.J. (1999). The implementation of EC environmental policy: A policy problem without a political solution? Environment and Planning C: Government and Policy, 17(1), 69-90.

Josselin, C. (1999). Quelle politique européenne de coopération au développement? In Short, C., Josselin, C., Schori, P. (Eds.). Europäische Regierungen zur Zukunft der Entwicklungszusammenarbeit. Grossbritannien, Frankreich, Schweden. (pp. 20-25). FES, Bonn 1999,

Kagan, R. (2003). Of paradise and power. America and Europe in the New World Order. New York: A. Knopf.

Keukeleire, S. (2006). EU core groups: Specialisation and division of labour in EU foreign policy. CEPS Working Document, No. 252, October 2006.

Keukeleire, S., \& MacNaughton, J. (eds), (2008). The foreign policy of the European Union. Basingstone: Palgrave Macmillan.

Lebow, R.N. (2007). Classical realism. In Dunne, T., Kurki, M. and Smith, S., International relations theories: Discipline and diversity. Oxford: University Press.

Louis, J.V., (2007). The European Union: from external relations to foreign policy? EU Diplomacy Papers, 2 /2007.

Mackenstein, H., \& Steve, M. (2005). The international relations of the European Union. London: Pearson.

Manners, I. (2006). Normative power Europe: A contradiction in terms? Journal of European Public Policy, 13 (2), 182-199.

Maull, H. W. (2005). Europe and the new balance of global order. International Affairs, 81 (4), 775-799.

Mall, H.M. (2006). Why Europe must hang together. In EPC. (Eds.). Dragons, elephants and tigers: adjusting to the new global reality. Challenge Europe Issue 15, September 2006, 84-85.

Mayer, H., \& Vogt, H. (2006). A responsible Europe? Ethical Foundations of EU External Affairs. Palgrave Macmillan.

McCormick, J. (2007). The European superpower. New York: Palgrave MacMillan. 
Meyer, J.W., Frank, D.J., Hironaka, A., Schofer, E. and Tuma, B.N. (1997). The structuring of a world environmental regime, 18701990. International Organization, 51 (4), p. 624.

Mitzen, J. (2006). Anchoring Europe's civilizing identity: habits, capabilities and ontological security. Journal of European Public Policy, 13 (2), 270-85.

Moravcsik, A. (2002). The quiet superpower. Newsweek.

Nye, J. (1999). Soft power. Foreign Policy, no. 80, Fall 1990.

Nye, J. (2004). Soft power. The means to succeed in world politics. New York: Public Affairs.

OECD/DAC. (2008). CRS database. downloaded in February 2009.

Orbie, J. (2008). Europe's global role: External policies of the European Union. Ashgate Publishing Limited. MPG Books.

Oxfam. (2010). UK multilateral aid review. August 2010.

Pijpers, A. (1988). The twelve out-of-area: A civilian power in an Uncivil World?. In Pijpers A., E. Regelsberger, W. Wessels, \& G. Edwards (Eds.). European political cooperation in the 1980s: A common foreign policy for Western Europe? Dordrecht: Martinus Nijhoff.

Preston, C. (1997). Enlargement and integration in the European Union. London: Routledge.

Pridham, G. (2005). Designing democracy: EU enlargement and regime change in post-communist Europe. Palgrave Macmillan, 2005.

Pridham, G. (2010). Change and continuity in the European Union's political conditionality: Aims, approach, and priorities. Democratization, 14 (3), 446-471.

Prodi, R. (2000). Speech at the European Parliament. 15.2.2000.

Rifkin, J. (2004). The European dream. New York: Penguin.

Sbragia, A. \& C. Damro. (1999). The changing role of the European Union in international environmental politics. Environment and Planning C: Government and Policy, 17(1), 53-68.

Schimmelfennig, F., \& Sedelmeier, U. (2002). Theorizing EU enlargement: research focus, hypotheses, and the state of research. Journal of European Public Policy, 9 (4), 500-528. 
Schimmelfennig, F., \& Sedelmeier, U. (2004). Governance by conditionality: EU rule transfer to the candidate countries of Central and Eastern Europe. Journal of European Public Policy. 11 (4), 669-687.

Schimmelfennig, F., and Sedelmeier, U. (eds). (2005). The politics of European Union enlargement: Theoretical approaches. London: Routledge.

Schimmelfennig, F. and Sedelmeier U. (eds). (2005). The Europeanization of Central and Eastern Europe. Ithaca: Cornell University Press.

Sedelmeier, U., \& Schimmenlfenning, F. (2005a). Introduction: Conceptualizing the Europeanization of Central and Eastern Europe. In Smith, S., Hadfield, A., \& Dunne, T. (2008). Foreign policy, theories, actors, cases. Oxford: University Press.

Sefano, M. (2006). Europe as a global actor: Priorities and perspectives of the EU's development policy. FIIA EU-Presidency Lecture Series, Helsinki, December 4, 2006.

Sjursen, H. (2002). Why expand? The question of legitimacy and justification in the EU's enlargement policy. JCMS, 40 (3), 491513.

Sjursen, H. (2006). The EU as a 'normative' power: how can this be? European Public Policy, 13, 235-251.

Sjursen, H. (2006). What kind of power? Journal of European Public Policy, 13 (2), 169-181.

Smith, E.M. (2004). Europe`s foreign and security policy - The institutionalization of cooperation. Cambridge: University Press.

Smith, K. (1998). The instruments of European foreign policy. In Zielonka, J., (Eds.). Paradoxes of European foreign policy. London: Kluwer Law International.

Smith, K.E. (2000). The end of civilian power EU: A welcome demise or cause for concern? The International Spectator, 25 (2), 11-28.

Smith, K.E. (2003). European Union foreign policy in a changing world. Cambridge: Polity Press. 
Smith, K. E. (2004). Still 'civilian power EU'? Paper presented at the CIDEL Workshop, 'From Civilian to Military Power: The European Union at a Crossroads?', Oslo.

Smith, K.E. (2005). Enlargement and European order. In Hill, C., \& Smith, M. (2005). International relations and the European Union. Oxford: University Press.

Smith, S., Hadfield, A., \& Dunne, T. (2008). Foreign policy, theories, actors, cases. Oxford: University Press.

Solana, J. (2003). A secure Europe in a better world. European security strategy.

Telo, M. (2007). Europe: A civilian power? European Union, global governance, world order. Palgrave Macmillan.

Vandenberghe, W. (2008). Preserving biodiversity in Europe: An infringement-led approach. Review of European Community and International Environmental Law, 17 (2), 243-6.

Verhofstadt, G. (2005). The United States of Europe. Federal Trust, chapter 9 .

Vogel, D., Toffel, M., Post, D., \& Aragon, N.U. (2010). Environmental federalism in the European Union and the United States. Harvard Business School, Working Paper, 10-085.

Vogler, J. (2005). The European contribution to global environmental governance. International Affairs, 81 (4), 835-50.

Waever, O. (2000). The EU as a security actor: Reflections from a pessimistic constructivist on post-sovereign security orders. In Keukeleire, S. \& MacNaughton, J., (Eds.). The foreign policy of the European Union. Basingstone: Palgrave Macmillan.

Wagner, W. (2006). The democratic control of military power Europe. Journal of European Public Policy, 13 (2), 200-216.

Weitsman, P. (1997). Intimate enemies: The politics of peacetime alliances. Security Studies, 7 (1), 191. 